\title{
INVESTIGATION OF THE ORGANIZATIONAL JUSTICE, PERCEIVED ORGANIZATIONAL SUPPORT AND ORGANIZATIONAL CYNICISM PERCEPTIONS OF ACADEMICIANS
}

\author{
Sinan Yalçın' ${ }^{1 \mathrm{i}}$, \\ Mehmet Özbaş² \\ ${ }^{1}$ Associate Professor, \\ Erzincan Binali Yıldırım University, \\ Turkey \\ ${ }^{2}$ Professor, \\ Erzincan Binali Yıldırım University, \\ Turkey
}

\begin{abstract}
:
This research, which aimed to investigate the relationship between organizational justice, perceived organizational support and organizational cynicism perceptions of academicians, was designed with the correlational survey model in the quantitative research pattern. The data of the research were collected with the organizational justice, perceived organizational support and organizational cynicism scales. The research was carried out with 132 academicians who were in-service in the Erzincan Binali Yildirım University located in the Eastern Anatolia Region of Turkey in 2019. The data of the research were analysed using the frequency, frequency, arithmetic mean, correlation and regression analysis. At the end of the research, it was found that the organizational justice, perceived organizational support of the academicians were at a high level, their organizational cynicism perceptions were at a low level. According to another result reached, there was a negative significant relationship between organizational justice, perceived organizational support perceptions and organizational cynicism perceptions of the academicians. At the end of the regression analysis, it was found that the academicians' organizational justice and perceived organizational support perceptions were a significant predictor of organizational cynicism.
\end{abstract}

Keywords: organizational justice, perceived organizational support, organizational cynicism, academician

${ }^{i}$ Correspondence: email sinan29@gmail.com 


\section{Introduction}

The increasing rate of change in today's world has made the adaptation of organizations to this change inevitable. The changes in local and global markets with the social and individual demands affect the organizations in every aspect. The organizations and living organisms have to adapt the change, prepare themselves for new situations and conditions. The reason for the existence of the organizations is their purpose. Organizations try to achieve their purpose. The purpose of the organizations is built upon the needs. Organizations, which cannot meet the needs and expectations of society and individuals, cannot survive. Therefore, organizations must perform change and transformation successfully following new environments. The behaviour of organizations to catch the change is one of the most important features that organizations should have today. As in all other organizations, even the education organizations aim to meet the needs and expectations of the society and individual by following the quick change. Meeting these expectations is realized both through the successful realization of education and training and by ensuring peace and justice among the staff of the organization. For organizational purposes to be achieved, organizational staff must work together in harmony for the success and dynamics of the organization (Güneş and Buluç, 2012).

Many factors such as awards and punishments distributed within the organization, communication of the staff with each other, application of the rules and wages at the end of the work performed to differentiate the staff perceptions of organizational justice. The negative attitude of staff in organizational justice perceptions negatively affects their organizational behaviour (Özdevecioğlu, 2003).

For an organization to achieve its purpose, in other words, to be successful, the most important element is the human resource in the organization. Organizations with qualified human resources have advantageous positions. The possibility of organizations to maintain these advantages depends on the continuation of qualified human resources. The fact that staff continue in the organization is related to meeting their expectations and needs in their organizational life. Factors such as the high commitment of staff towards organizational and perception of organizational justice can be considered among the crucial factors that ensure the continuity of qualified human resources in organizations.

\section{Organizational Justice}

The concept of justice is an important concept that affects and directs the relationships between individuals. If it is considered in terms of the organizations, justice can be considered as an important factor in terms of keeping the human resources in the organization in the relations between management-staff, staff -staff. Staff regard whether they are treated fairly and whether their needs and expectations in return for their performance for the organization are met or not. They consider the issues such as wage 
and promotion, which are the equivalent of their efforts, with the concept of justice and make their evaluations accordingly. Thus, they identify their perceptions of organizational justice.

Organizational justice can be defined as "the way that staff perceive how rewards and penalties are applied within the organization, how decision-making processes related to the implementation of rewards and punishments are operated" (İçerli, 2010). According to another definition, the organizational justice is explained as a set of rules and social norms regarding the distribution of organizational resources, the criteria taken into account in determining these distribution decisions, and how interpersonal behaviours during the execution of these procedures should be (Çakmak, 2005).

One of the vital factors in the performance of staff for organizational purposes, ensuring staff continuity, and increasing the staff productivity is the high perception of justice in the organization. Staff struggle for the organization as their perception of organizational justice increases and they continue to be a volunteer in the organization. As a result of this, the staff can fulfil the performance expected of them. Otherwise, the staff with low loyalty, low level of identification with the organization, thus increasing behaviour to leave the organization to emerge (Örücü and Özafşaroğlu, 2013).

The concept of organizational justice is generally described under 3 headings in the literature. Staff's perception of justice regarding the distribution of resources is named as distributional justice, the perception of justice regarding the decisions taken during the distribution of resources as procedural justice, and the interaction of staff in the same and different positions in the organization with each other as interactional justice (Camerman, Cropanzano and Vandanberghe, 2007; Colquitt and Greenberg, 2003: 165; Trans: Bal, 2014)

\section{Organizational Cynicism}

The concept of cynicism, which first appeared as a negative reaction of people against unethical behaviours in Ancient Greece (Bedük, 2014), expresses the negative attitudes of individuals emerging as a result of the behaviours demonstrated by individuals today (Akdemir, Kırmızıgül and Zengin, 2016). Although cynicism has many definitions in terms of different disciplines, it can be explained as the belief that it does not trust the intentions of others and does not reflect the main characters of those concerned (Helvac1 and Çetin, 2012). People who think that individuals only take care of their interests and who consider everyone to be self-interested in this direction are defined as "cynic" and the idea of trying to explain this situation is called as "cynicism" (Karacaoğlu and İnci, 2012).

Organizations are forced to change by external factors to perceive the changes occurring in their environment. Organizational change efforts may negatively affect staff's behaviour within the organization (Tokgöz and Yılmaz, 2008). 
Cynicism can be regarded as a negative attitude that people take to gain interest in groups, order or organization (Andersson, 1996). The demonstration of cynical behaviours against the organization is referred to as organizational cynicism. Organizational cynicism emerges when the staff have negative thoughts about their organizations (Karacaoğlu and İnce 2013: Torun and Üçok, 2014). At the background of the organizational cynicism concept, there is the belief that organizations are devoid of concepts such as truth, honesty and justice (Torun and Üçok, 2014).

The emergence of organizational cynicism brings with it many problems such as hopelessness, distrust and disappointment (Andersson and Bateman, 1997; Byne and Hochwarter, 2007). These feelings emerging among the staff can negatively affect the organizational beliefs as well as the performance of the staff. It is an important issue for organizations to recognize the cynical attitudes and behaviours that arise in the organization and to manage this situation successfully (Tokgöz and Y1lmaz, 2008).

\section{Perceived Organizational Support}

For the staff to work effectively and efficiently in the organization, they must first feel safe and perceive themselves as part of the organization (Demir, 2010). Ensuring that staff struggle for the organization is among the primary duties of organization managers. Managers can ensure that staff create a performance for the organization by creating appropriate working conditions for staff, making staff feel that they are a valuable member of the organization, and providing them with the necessary support (Eisenberger, Huntington, Hutchison and Sowa, 1986; Trans. Giray and Şahin, 2012).

Organizational support can be defined as being aware of the staff's contributions to the organization and paying attention to their well-being (Akın, 2008). Organizations that support their staff value them, emphasize that they are important for the organization, care about their staff's expectations and needs, and create a suitable working environment and conditions for their staff. Thanks to this, organizations can ensure that their staff gather around organizational goals, enabling them to demonstrate the performance required for organizational goals.

\section{Method}

The quantitative research pattern was employed in this research, which aimed to investigate the relationship between organizational justice, perceived organizational support and organizational cynicism perceptions of academicians. The research was designed with the correlational survey model.

\subsection{Study Group}

The study group of the research consisted of 132 academicians who were in-service in the Erzincan Binali Yıldırım University located in the Eastern Anatolia Region of Turkey in 
2019. The demographic information of the academics participated in the research is presented in Table 1 below.

Table 1: Demographic Information

\begin{tabular}{|l|c|c|c|c|c|c|c|}
\hline Topics & & $\mathbf{1}$ & $\mathbf{2}$ & $\mathbf{3}$ & $\mathbf{4}$ & $\mathbf{5}$ & Total \\
\hline Gender & & Male & Female & & & & - \\
& $\eta$ & 103 & 29 & & & & 132 \\
& $\%$ & 78 & 22 & & & & 100 \\
\hline Degree & & Prof & Assoc. & Dr. Lec & Res. Asst & Lecturer & - \\
& $\eta$ & 9 & 22 & 51 & .34 & 16 & 132 \\
& $\%$ & 6,8 & 16,7 & 38,6 & 25,8 & 12,1 & 100 \\
\hline Age & & $\mathbf{2 0 - 3 0}$ & $\mathbf{3 1 - 4 0}$ & $\mathbf{4 1 - 5 0}$ & $\mathbf{5 1 +}$ & & - \\
& $\eta$ & 26 & 60 & 26 & 20 & & 132 \\
& $\%$ & 19,7 & 45,5 & 19,7 & 15,2 & & 100 \\
\hline In-service Year & & $\mathbf{1 - 5}$ & $\mathbf{6 - 1 0}$ & $\mathbf{1 1 - 1 5}$ & $\mathbf{1 6 - 2 0}$ & $\mathbf{2 1 -}$ & \\
& $\eta$ & 40 & 36 & 19 & 10 & 27 & 132 \\
& $\%$ & 30.3 & 27,3 & 14,4 & 7,6 & 20,5 & 100 \\
\hline Marital Status & & Married & Single & & & & \\
& $\eta$ & 97 & 35 & & & & 132 \\
& $\%$ & 73,5 & 26,5 & & & & 100 \\
\hline
\end{tabular}

\subsection{Data Collection Tools}

\section{a. Organizational Justice Scale}

The "Organizational Justice Scale", which was developed by Niehoff and Moorman (1993), was used to determine staff' perceptions of organizational justice in this research. There are three sub-dimensions on this scale which consists of 20 items in total. The interactional justice dimension consists of 9 items, procedural justice consists of 6 items, and the distributional justice dimension consists of 5 items. Polat (2007) performed the Turkish adaptation of the scale.

\section{b. Perceived Organizational Support Scale}

To determine the organizational support perceptions of the staff, the scale, which was developed by Eisenberger et al., (1986) and shortened to 10 questions by Stassen and Ursel (2009), was applied. Akkoç, Çalışkan and Turunç (2012) translated the scale, which was prepared as in the 5 points Likert type, into Turkish. The scale is single-dimensional and consists of 10 items.

\section{c. Organizational Cynicism Scale}

The scale named "Organizational Cynicism" developed by Brandes, Dharwadkar and Dean (1999) was adapted into Turkish by the study Kalağan (2009). The scale consists of 13 items and 3 dimensions and is arranged according to a 5-point Likert scale. Dimensions included in the scale; cognitive, affective and behavioral dimensions. 1.-5. items cognitive dimension, 6.-9. items affective dimension and 10.-13. items represent the behavioral dimension. 5-point Likert type scale; It was scored as "5= Agree", "4= Agree", "3 = Partially Agree", "2 = Disagree", "1 = Never Agree". The reliability of the scale was 
calculated with the Cronbach Alpha Internal Consistency Coefficient. As a result of the calculation, the Cronbach's Alpha Coefficient was determined as .91 for the cognitive dimension, .90 for the affective dimension, .96 for the behavioral dimension and .74 for the overall scale. Looking at these results, it can be said that the Turkish version of the Organizational Cynicism Scale is valid and reliable.

\subsection{Analysis of the Data}

The normality assumption test was applied to determine whether the data obtained from the research provides normal distribution. As a result of the analysis, it has been determined that the data showed normal distribution. Information regarding the normal distribution of the data is presented in Table 2. After the data were found to be normally distributed, analyses were carried out in line with the sub-problems of the research. In the analysis of the data, the correlation and regression analysis were performed through the SPSS package program. The results of the analysis are presented in the findings section.

Table 2: Normality Test Results

\begin{tabular}{|l|c|c|}
\hline Dimensions & Skewness & Kurtosis \\
\hline Organizational Justice &,- 050 &,- 595 \\
\hline Procedural justice &, 060 &,- 381 \\
\hline Distributional justice &,- 214 &,- 470 \\
\hline Interactional justice &,- 328 &,- 518 \\
\hline Perceived Organizational Support &,- 130 &,- 201 \\
\hline Organizational Cynicism &, 178 &,- 406 \\
\hline Cognitive cynicism &, 274 &,- 381 \\
\hline Affective cynicism &, 901 &, 611 \\
\hline Behavioural cynicism &,- 289 &,- 640 \\
\hline
\end{tabular}

\section{Findings}

In this part of the research, the findings gathered from the analysis of the data and interpretations handled related to these data are included.

Table 3: The Organizational Justice, Perceived Organizational Support and Organizational Cynic Perception Levels of the Academicians

\begin{tabular}{|l|c|c|c|}
\hline & $\mathbf{N}$ & $\mathbf{X}$ & Sd \\
\hline Perceived organizational support & 132 & 3,40 &, 64 \\
\hline Organizational justice & 132 & 3,63 &, 69 \\
\hline Distributional justice & 132 & 3,80 &, 72 \\
\hline Interactional justice & 132 & 3,80 &, 83 \\
\hline Procedural justice & 132 & 3,21 &, 86 \\
\hline Organizational Cynicism & 132 & 2.51 &, 68 \\
\hline Cognitive cynicism & 132 & 2,77 &, 84 \\
\hline Affective cynicism & 132 & 2,02 &, 89 \\
\hline Behavioural cynicism & 132 & 2,70 &, 83 \\
\hline
\end{tabular}


As Table 3 is analysed, it can be claimed that the perceived organizational support of the academicians $(X=3,40)$, the organizational justice $(X=3,63)$, distributional justice $(X=3,80)$ and interactional justice $(X=3,80)$ perceptions are at a high level. Besides, the procedural justice $(X=3,21)$, cognitive cynicism $(X=2,77)$ and behavioural cynicism $(X=2,70)$ perceptions of the academicians are moderate, and their effective cynicism $(X=2,02)$ and organizational cynicism $(X=2,51)$ perceptions are at a low level.

According to these findings, it can be referred that the academicians got the necessary support from the organizations that they were in. It is seen that academics are managed with a fair management mentality, results and awards are distributed fairly among the staff, and academics have positive thoughts towards both their organizations and managers. It can be said that the managers communicate with the staff in the framework of respect and love. Also, academics have a moderate level of perception of running formal processes in their organizations, distributing awards and participating in decision-making processes. The answers, which were given by the academicians, generally show that they do not have negative opinions about their organizations. They do not have feelings like anger, shame, and disrespect towards their organization. In Table 4, there are analyses of the relationship between academicians' organizational justice, organizational support and cynicism perceptions.

Table 4: The relationship between academicians' organizational justice, organizational support and cynicism perceptions

\begin{tabular}{|c|c|c|c|c|c|c|c|c|}
\hline Dimensions & 1 & 2 & 3 & 4 & 5 & 6 & 7 & 8 \\
\hline 1. Organizational Justice & 1 & & & & & & & \\
\hline 2. Perceived Organizational Support &, $754^{* *}$ & & & & & & & \\
\hline 3. Organizational Cynicism &,$- 641^{* *}$ &,$- 665^{* *}$ & & & & & & \\
\hline 4. Procedural Justice &, $821^{* *}$ &, $657^{* *}$ &,$- 678^{* *}$ & & & & & \\
\hline 5. Distributional Justice &, $761^{* *}$ &, $561^{* *}$ &,$- 410^{* *}$ & $484^{* *}$ & & & & \\
\hline 6. Interactional Justice & $916^{* *}$ & $671^{* *}$ &,$- 520^{* * *}$ &, $595^{* *}$ & , $592^{* *}$ & & & \\
\hline 7. Cognitive Cynicism &,$- 644^{* *}$ &,$- 685^{* *}$ & $855^{* *}$ &,$- 691^{* *}$ & $-436^{* *}$ &,$- 504^{* *}$ & & \\
\hline 8. Affective Cynicism &,$- 491^{* *}$ &,$- 486^{* *}$ & , $798^{* *}$ &,$- 459^{* *}$ &,$- 386^{* *}$ &,$- 405^{* *}$ &, $540^{* *}$ & \\
\hline 9. Behavioural Cynicism &,$- 369^{* *}$ &,$- 386^{* *}$ & ,731* &,$- 441^{* *}$ &,- 129 &,$- 316^{* *}$ & $435^{* *}$ & $374^{* *}$ \\
\hline
\end{tabular}

As Table 4 is analysed, it can be referred that there is positive significant relationship between the perceived organizational support and the organizational justice perceptions $(R=, 754)$ of the academicians; and negatively significant relationship between the perceived organizational support, organizational justice and the organizational cynicism perceptions $(\mathrm{R}=-, 641, \mathrm{R}=-, 665)$. As it is evaluated in terms of the sub-dimensions, it can be claimed that there is a positive significant relationship between the sub-dimensions of the organizational justice as procedural justice $(R=, 657)$, distributional justice $(R=, 561)$ and interactional justice $(\mathrm{R}=, 671)$ dimensions and the perceived organizational support; on the other hand, there is negatively significant relationship between the organizational cynicism and the procedural justice $(R=-, 678)$, distributional justice $(R=-, 410)$, interactional justice $(\mathrm{R}=-, 520)$. According to these findings, as the perceived organizational support the academicians' perceptions increase, the organizational justice 
perceptions increase as well, with the increase in their perceived organizational support and organizational justice perceptions, their organizational cynicism perceptions decrease. The regression analysis results related to the interpretation of the cognitive cynicism are presented in Table 5.

Table 5: The regression analysis results related to the interpretation of the cognitive cynicism

\begin{tabular}{|l|c|c|c|c|c|}
\hline Cognitive Cynicism & B & SHв & $\boldsymbol{\beta}$ & $\mathbf{t}$ & $\mathbf{p}$ \\
\hline Constant & 29,596 & 1,491 & & 19,847 &, 000 \\
\hline Perceived organizational support &,- 279 &, 059 &,- 423 & $-4,759$ &, 000 \\
\hline Procedural justice &,- 354 &, 066 &,- 433 & $-5,387$ &, 000 \\
\hline Distributional justice &,- 021 &, 088 &,- 018 &,- 238 &, 812 \\
\hline Interactional justice &, 028 &, 049 &, 049 &, 567 &, 572 \\
\hline $\mathrm{R}=0,756 \mathrm{R}^{2}=0,572 \mathrm{p}=0,000$ & \multicolumn{4}{|l}{} \\
\hline
\end{tabular}

As Table 5 is analysed, it is seen that the organizational support is a significant predictor on the cognitive cynicism, which is the sub-dimension of organizational cynicism, and on the procedural justice which is the sub-dimension of the organizational justice; and it is understood that the perceived organizational support and the procedural justice together explain $57,2 \%$ of the change in the variable of cognitive cynicism.

Table 6: The regression analysis results related to the prediction of the effective cynicism

\begin{tabular}{|l|c|c|c|c|c|}
\hline Affective Cynicism & $\mathbf{B}$ & $\mathbf{S H}$ & $\boldsymbol{\beta}$ & $\mathbf{t}$ & $\mathbf{p}$ \\
\hline Constant & 18,564 & 1,630 & & 11,390 &, 000 \\
\hline Perceived organizational support &,- 142 &, 064 &,- 255 & $-2,214$ &, 029 \\
\hline Procedural justice &,- 146 &, 072 &,- 213 & $-2,040$ &, 043 \\
\hline Distributional justice &,- 117 &, 096 &,- 119 & $-1,216$ &, 226 \\
\hline Interactional justice &,- 018 &, 053 &,- 037 &,- 334 &, 739 \\
\hline $\mathrm{R}=0,531 \mathrm{R}^{2}=0,282 \mathrm{p}=0,000$ & \multicolumn{4}{|l}{} \\
\hline
\end{tabular}

In Table 6, the regression analysis results related to the prediction of the effective cynicism are presented. It is seen that the perceived organizational support is a significant predictor on the effective cynicism, which is the sub-dimension of organizational cynicism, and on the procedural justice, which is the sub-dimension of the organizational justice; that the perceived organizational support and procedural justice together explain the $28,2 \%(\mathrm{R} 2=, 282)$ of the change in the variable of the effective cynicism.

Table 7: Regression Analysis Results Related to the Prediction of the Behavioural Cynicism

\begin{tabular}{|l|c|c|c|c|c|}
\hline Behavioural Cynicism & B & $\mathbf{S H}_{\mathbf{B}}$ & $\boldsymbol{\beta}$ & $\mathbf{t}$ & $\mathbf{p}$ \\
\hline Constant & 16,574 & 1,567 & & 10,578 &, 000 \\
\hline Perceived organizational support &,- 112 &, 062 &,- 216 & $-1,821$ &, 071 \\
\hline Procedural justice &,- 225 &, 069 &,- 350 & $-3,260$ &, 001 \\
\hline Distributional justice &, 198 &, 092 &, 215 & 2,140 &, 034 \\
\hline Interactional justice &,- 040 &, 051 &,- 090 &,- 787 &, 433 \\
\hline $\mathrm{R}=0,488 \mathrm{R}^{2}=0,239 \mathrm{p}=0,000$ &
\end{tabular}


In Table 7, there are the regression analysis results related to the prediction of the behavioural cynicism. The procedural justice and distributional cynicism, which are the sub-dimensions of organizational justice, are the significant predictor on the behavioural cynicism, which is the sub-dimension of the organizational cynicism; and the procedural justice and distributional justice together explain $23,9 \%(\mathrm{R} 2=, 239)$ of the change in the variable of behavioural cynicism.

Table 8: The Regression Analysis Results Related

to the Prediction of the Organizational Cynicism

\begin{tabular}{|l|c|c|c|c|c|}
\hline Organizational Cynicism & B & SHB & $\boldsymbol{\beta}$ & $\mathbf{t}$ & $\mathbf{p}$ \\
\hline Constant & 67.641 & 3.204 & & 21.110 & .000 \\
\hline Organizational justice & -.208 & .062 & -.324 & -3.372 & .000 \\
\hline Perceived organizational support & -.585 & .133 & -.421 & -4.382 & .000 \\
\hline $\mathrm{R}=0,698 \mathrm{R}^{2}=0,487 \mathrm{p}=0,000$ &
\end{tabular}

In Table 8, there are the regression analysis results related to the prediction of the organizational cynicism. It is seen that both the organizational justice and the perceived organizational support are the significant predictor on the organizational cynicism, and the organizational justice and perceived organizational support explain $48,7 \%\left(\mathrm{R}^{2}=, 487\right)$ of the change in the variable of the organizational cynicism.

\section{Discussion}

Organizational life depends primarily upon the positive perception of organizational justice, organizational trust and organizational support of staff. Staff can maintain their behaviour and desire to stay in the organization and make efforts for their organizations, as long as they feel safe. The achievement of organizations depends on their staff performance in line with their organizational goals. Among the factors that cause the performance of the staff to increase, their perception of organizational justice and the support they expect from the organization are of great importance. In this scope, providing justice within the organization and ensuring the necessary organizational support to staff is a primary function in terms of achieving organizational goals. As in all around the world, the organizational life in Turkey is significantly affected by global changes and developments, and individual and social demands. People mostly spend their lives in social organizations, along with business and professional organizations. The staff in Turkey, as a country that has adopted the culture of democracy, the staff mostly attach importance to gaining a sense of trust in organizational life. Gaining the staff's feelings of trust is about ensuring justice in the organization and positive attitudes towards them.

The following results were reached in accordance with the findings handled in this research, in which the relationship between the organizational justice, perceived organizational support and organizational cynicism perceptions of the academicians was investigated. 
According to the results gathered at the end of the research, the perceived organizational support perceptions of academicians are in a rate that can meet their expectations and in a positive direction. Depending on this result, it can be claimed that the academicians thought that they got enough support from their organizations. According to another result, it was determined that academicians' perceptions of organizational justice were higher in distributional and interactional justice dimensions. As the literature is reviewed, it is noticed that the results of the researches conducted by Yazıcıoğlu and Topaloğlu (2009), Titrek (2009), Altınkurt and Yılmaz (2010), Yılmaz (2010) support the results of this research. In addition, in another research by Turunç (2011), it was reached that the interactional justice perceptions of the staff were high; on the other hand, the procedural and distributional justice perceptions were at a moderate level. In the research by Yavuz (2010), it was found that the organizational justice perceptions of the staff in the private sector were higher compared with the public staff. In the researches conducted by Çırak (2013), Polat and Celep (2008), Baş and Şentürk (2011), it was found that the distributional, procedural and interactional justice perceptions of teachers were high. In the researches by Ünlü, Hamedoğlu and Yaman (2015), the organizational justice perceptions of teachers were at a moderate level at the dimension of the distributional justice; at a high level at the procedural and interactional dimensions. In the research by Ay and Koç (2014), the results, that the distributional and procedural justice perceptions of teachers were at a moderate level; on the other hand, the interactional justice perceptions were high, were reached. Also, in the researches by Pillai, Scandura and Williams (1999), Estreder, Rigotti, Tomas and Ramos (2020), and Berkovits (2018), the procedural justice perceptions of the staff were found to be moderate. Blakely, Andrews and Moorman (2005), Tyagi, Moses and Rana (2017) reached to the results in their studies that the participants' organizational justice perceptions were high. Hussain and Khan (2018) found in their study that the staff's procedural justice perceptions were moderate, distribution as justice perceptions were low and interactional justice perceptions were high.

In addition, it was found that the academicians' procedural justice, cognitive cynicism and behavioural cynicism perceptions were moderate, the affective cynicism and organizational cynicism perceptions were at a low level. In their study, Kalağan and Güzeller (2010) found that the organizational cynicism perceptions of teachers were moderate. In another study by Şirin (2011), Kılıç (2011), Ergen (2015), the organizational cynicism perceptions of teachers were low. Çetin, Özgan and Bozbayındır (2011), Özgan, Çetin and Külekçi (2011) found in their studies that the organizational cynicism perceptions of teachers were low. In the study by Kalağan (2009), Polat, Meydan and Tokmak (2010) carried out with academicians, the organizational cynicism perceptions of the academicians were at a moderate level. In a study on academicians by Arslan (2012), the organizational cynicism levels of the academicians were found to be low.

The results show that the academicians get support from the organizations they are in. According to the results, it can be claimed that a fair management understanding is dominant in the management process of the organizations in which academicians are 
in service, that the awards are distributed fairly among the staff in their organizations, academicians have positive thoughts both against their organizations and managers, and the communication process of the staff of the organization is created in the framework of mutual respect and love. Besides, it can be stated that the academicians have a moderate level perception in the organization of formal processes, distribution of awards and participation in decision-making processes. According to the answers by the academicians, it can be referred that they do not have negative thoughts about their organizations, and they do not have feelings such as anger, shame, and disrespect towards their organizations in general.

According to the results gathered from the research, it was found that there was a positive significant relationship between the academicians' perceived organizational support perceptions and organizational justice perceptions; that there was a negative significant relationship between the perceived organizational support, organizational justice and the organizational cynicism perceptions. In the studies conducted by Çetin, Özgan and Bozbayındır (2011), Efeoğlu and İplik (2011), Güzel and Ayazlar (2014), Özgen and Turunç (2017), Turgut and Agun (2016), Mavibaş and Belli (2018), Kanbur and Canbek (2018), Acaray (2019), Erturhan Işkın (2018), Şamdan and Atanur Baskan (2019), Yazıcıoğlu and Özcan Gençer (2017), it was concluded that there was a negative relationship between the organizational justice and organizational cynicism. As it is evaluated in terms of the sub-dimensions, it can be stated that there is a positive relationship between the dimensions of organizational justice, procedural justice, distributional justice and interactional justice, and perceived organizational support, and there is a negative relationship between organizational cynicism and procedural justice, distributional justice and interactional justice. According to the gathered results, it can be referred that as perceptions of perceived organizational support of academicians increase, perceptions of organizational justice also increase, and there is a decrease in their perceptions of organizational cynicism.

According to another result reached in the research, it was determined that the perceived organizational justice perceptions of the academicians and organizational support perceptions are significant predictors of organizational cynicism. This result shows similarity with the results of the study conducted by Kanbur and Canbek (2018). In the literature, in the studies by Turgut and Agun (2016), Özgen and Turunç (2017), Yazıcıŏlu and Özcan Gençer (2017), Biswas and Kapil (2017), Bernert, Armenakis, Feild and Walker (2007), Shaharruddin, Ahmad and Muhaizam Musa (2016), they found that the organizational justice is a significant predictor on the organizational cynicism. In the studies by Kerse and Karabey (2017), Peplinski (2014), it was found that the organizational cynicism was a significant predictor on the organizational cynicism. With this research conducted in Turkey, it was observed that the results gathered from the other researches demonstrate similarity with the international research results in the literature. 


\section{Conclusions and Recommendations}

In organizations in which the sense of justice is powerful, the negative thoughts of the staff about their organizations will decrease. When staff fail to meet their expectations, they can engage in several negative feelings, thoughts, and behaviours related to the organization. The decrease in the organizational justice perceptions of the staff will have a negative effect on many issues concerning the effectiveness and efficiency of the organization, such as a decrease in their job performance, weakening in their organizational commitment, low job satisfaction, and low motivation.

Besides, as it was evaluated in terms of the sub-dimensions of the organizational cynicism, it was concluded that academicians' perceived organizational support and procedural justice perceptions were significant predictors of their cognitive cynicism perceptions; on the other hand, their distributional justice and interactional justice perceptions were not significant predictors of cognitive cynicism.

As it was evaluated in terms of the behavioural cynicism, it was concluded that the academicians' procedural justice perceptions were significant predictors of behavioural cynicism; on the other hand, their perceived organizational support, distributed justice and interactional justice perceptions were not significant predictors of their behavioural cynicism perceptions. According to another result gathered from the research, it was found that the academicians' perceived organizational support, procedural justice, distributional justice and interactional justice perceptions were not significant predictors of effective cynicism.

It is expected that as the positive attitudes of academicians towards organizational justice increase and as they get the support they desire from their organizations, their negative thoughts towards their organizations will tend to decrease. Several factors that affect the behaviour of organizational cynicism can be mentioned. The effect of the organizational justice and perceived organizational support perceptions on the organizational cynicism was investigated in this study. Researches related to the effect of other variables on organizational cynicism can be conducted.

\section{Conflict of Interest Statement}

The authors declare that there are no conflicts of interest

\section{About the Authors}

Sinan Yalçın is working as Associate Professor at Erzincan Binali Yıldırım University in Turkey, Faculty of Education, Department of Educational Sciences, Department of Education Management. His research interests are classroom management, leadership and school administration.

Mehmet Özbaş is working as a Professor Doctor in Erzincan Binali Yıldırım University, Faculty of Education, Department of Educational Sciences, Department of Education Management. His research interests are classroom management, leadership, school administration, disadvantaged children, absenteeism. 


\section{References}

Acaray, A. (2019). The moderating effect of power distance on organizational justice and organizational cynicism. International Journal of Economic and Administrative Studies, 24, pp. 197-214.

Akdemir, B., Kırmızıgül, B. \& Zengin, Y. (2016). The relationship between organization cynicsm and job performance: a research. Journal of Kahramanmaraş Sütçü İmam University Faculty of Economics and Administrative Sciences, 6(2), pp. 115-130.

Akın, M. (2008). The effects of organizational support, social support and work/family conflicts on life satisfaction. Journal of Social Sciences Institute of Erciyes University, 25, pp. 141-170.

Altınkurt, Y. \& Y1lmaz, K. (2010). Examining the relationship between management by values and organizational justice by secondary school teachers' perceptions. Educational Administration: Theory and Practice, 16(4), pp. 463-484.

Altınöz, M., Çöp, S. \& Sığındı, Taner. (2010). Relationship between perceived organizational commitment and organizational cynicism: a research on four and five star accommodation establishments in Ankara Selcuk University Faculty of Economics and Administrative Sciences Journal of Social and Economic Research, 11(21), pp. 285-315.

Andersson, L. (1996). Employee cynicism: an examination using a contract violation framework. Human Relations, 49, 1397-1418.

Andersson, L. M. \& Bateman, T. S. (1997). Cynicism in the Workplace: Some Causes and Effects. The Journal of Organizational Behavior, 18, pp. 449-470.

Arslan, E. T. (2012). Cynicism and organizational cynicism trends of academicians at Suleyman Demirel university faculty of economics and administrative sciences. Journal of Doğuş University, 13(1), pp. 12-27.

Ay, G., \& Koç, H. (2014). Determine the Relation between Perception of Organizational Justice and Level of Organizational Commitment: Study Case of Teachers. Journal of Business Research, 6(2), pp. 67-90.

Bal, V. (2014). Relations of Organizational Justice and Organizational Commitment: A Research in Educational Institutions in Manisa. Journal of Aksaray University Faculty of Economics and Administrative Sciences, 6 (1), 1-9.

Baş, G. \& Şentürk, C. (2011). Elementary School Teachers' Perceptions of Organisational Justice, Organizational Citizenship Behaviours and Organisational Trust. Educational Administration: Theory and Practice, 17(1), pp. 29-62.

Bedük, A. (2014). Organizational psychology (2. Edition). Konya: Atlas Academy.

Bernerth, J. B., Armenakis, A. A., Feild, H. S., \& Walker, H. J. (2007). Justice, cynicism, and commitment: A study of important organizational change variables. The Journal of Applied Behavioral Science, 43 (3), 303-326.

Biswas, S., \& Kapil, K. (2017). Linking perceived organizational support and organizational justice to employees' in-role performance and organizational 
cynicism through organizational trust. Journal of Management Development, 36 (5), pp. 696-711.

Blakely, G. L., Andrews, M. C. \& Moorman, R. H. (2005). The moderating effects of equity sensitivity on the relationship between organizational justice and organizational citizenship behaviors. Journal of Business and Psychology, 20(2), pp. 259-273.

Byrne, Z. S. \& Hochwarter, W. A. (2007). Perceived Organizational Support and Performance Relationships Across Levels of Organizational Cynicism. Journal of Managerial Psychology, 23(1), pp. 54-72.

Çakmak, K.Ö. (2005). Organizational justice perception in performance evaluation systems and a case study. Unpublished Master Thesis. Istanbul University Institute of Health Sciences. Istanbul Turkey.

Çetin, B., Özgan, H. \& Bozbayındır, F. (2013). Examining the relationship between primary school teachers' perception of organizational justice and cynicism. Journal of Academic View, 37, pp. 1-20.

Çırak, S. (2013). Perception organizational justice of primary school teachers. Unpublished Master's Thesis, Hacettepe University Institute of Social Sciences, Ankara / Turkey.

Dean Jr, J. W., Brandes, P. \& Dharwadkar, R. (1998). Note organizational cynicism. The Academy of Management Review, 23, pp. 341-352.

Demir, M. (2010). The effects of emotional intelligence on human resources selection: A research on managers of accommodation enterprises. International Journal of Human Sciences, 7(1), pp. 1066-1081.

Dishon-Berkovits, M. (2018). The role of organizational justice and stress in predicting job burnout. Journal of Career Development, 45(5), pp. 411-424.

Efeoğlu, İ. E. \& İplik, E. (2011). An application in the pharmaceuticals sector to determine the effects of the perceived organizational justice on organizational synthesis. Journal of Çukurova University Institute of Social Sciences, 20(3), pp. 343-360.

Ergen, S. (2015). The relationship between teachers' organizational cynicism levels and organizational commitment. Unpublished Master's Thesis, Gazi University, Institute of Educational Sciences, Ankara / Turkey.

Erturhan Işkın, H. (2018). The impact of organizational justice on organizational citizenship, organizational cynicism and organizational revenge. Unpublished Doctoral Thesis. Cumhuriyet University Institute of Social Sciences, Sivas.

Eryeşil, K. ve Fındık, M. (2011). Organizational cynicism. (Ed: Aykut Bedük). Organizational psychology: new approaches, current issues (pp. 97-118). Konya: Atlas Academy.

Estreder, Y., Rigotti, T., Tomás, I. \& Ramos, J. (2020). Psychological contract and organizational justice: The role of normative contract. Employee Relations, 42(1), pp. 17-34.

Giray, M. D. \& Sahin, D. N. (2012). Perceived Organizational, Manager and Colleagues Support Scales: Validity and Reliability Study. Turkish Psychology Articles, 15(30), pp. 1-9. 
Güneş, A. M. \& Buluç, B. (2012). The relationship between transformer leadership and organizational justice in primary schools. Turkish Journal of Educational Sciences, 10(3), 411-437.

Güzel, B. \& Ayazlar, G. (2014). The Effect of Organizational Justice Towards Organizational Cynicism and Job Quit Intentions: A Research on Hotels. Journal of Karamanoğlu Mehmetbey University Social and Economic Research, 16(26), pp. 133-142.

Helvac1, M. A. \& Çetin, A. (2012). Determining the organizational cynicism levels of teachers working in primary schools. Turkish Studies, 7(3), pp. 1475-1497.

Hussain, M. \& Khan, M. S. (2018). Organizational justice and turnover intentions: probing the Pakistani print media sector. In Evidence-based HRM: a Global Forum for Empirical Scholarship. Emerald Publishing Limited.

İçerli, L. (2010). Organizational justice: a theoretical approach. Journal of Entrepreneurship and Development, 5 (1), 67-92.

Kalağan, G. (2009). The relationship between research assistants' perceptions of organizational support and organizational cynicism. Unpublished Master's Thesis, Akdeniz University Institute of Social Sciences, Antalya.

Kalağan, G. \& Güzeller, C. O. (2010). The Organizational Cynicism Levels of the Teachers. Pamukkale University Journal of Education, 27, pp. 83-97.

Kanbur E. \& Canbek M. (2018). The effect of perceived organizational justice on organizational cynicism: mediating role of perceived organizational support. Business \& Management Studies: An International Journal, 6(3), pp. 36-57.

Karacaoğlu, K. \& İnce, F. (2012). Reliability and validity of the Turkish version of brandes, dharwadkar, and dean's (1999) organizational cynicism scale: The Case of Organized Industrial Zone, Kayseri: Business and Economics Research Journal, 3(2), pp. 77-92.

Kasalak, G. \& Aksu, M. B. (2014). The relationship between perceived organizational support and organizational cynicism of research assistants. Educational Sciences: Theory \& Practice, 14(1), pp. 125-133.

Kerse, G., \& Karabey, C. N. (2017). The effects of perceived organizational support on organizational identification: the mediating role of organizational cynicism. MANAS Journal of Social Studies, 6 (4), 375-398.

Kılıç, Ş. (2011). The relationship between organizational cynicism and organizational commitment levels of primary school teachers (Keçiören ilçesi örneği). Unpublished Master Thesis. Hacettepe University, Institute of Educational Sciences. Ankara Turkey.

Koçoğlu, M. (2014). Cynicism as a mediator of relations between job stress and work alienation a study from a developing country Turkey, Global Business and Management Research an International Journal, 6(1), pp. 24-36.

Mavibaş, M. \& Belli, E. (2018). The investigation of organizational justice perception and organizational cynicism attitudes of the academic personnel in the faculties of sports science. ETU Journal of Social Sciences Institute, 3(6), pp. 121-133. 
Mete, Y. A. (2013). Relationship between organizational cynicism and ethical leadership behaviour: a study at higher education, Procedia - Social and Behavioral Sciences, 89, pp. 476-483.

Naus, F., Iterson, A. \& Roe, R. (2007). Organizational cynicism: Extending the exit, voice, loyalty, and neglect model of employees' responses to adverse conditions in the workplace. Human Relations, 60(5), pp. 683-718.

Neves, P. (2012). Organizational cynicism: Spillover effects on supervisor-subordinate relationships and performance. The Leadership Quarterly, 23, pp. 965-976.

Örücü, E. \& Özafşarlıoğlu, S. (2013). The influence of organizational justice on the turnover intention: a study in the republic of South Africa. Mustafa Kemal University Journal of Social Sciences Institute, 10(23), pp. 335-358.

Özbek, M. F. \& Kosa, G. (2009). The influence of affective commitment, organizational support, upper management support and empowerment on service quality: a study of bank employees in Kyrgyzstan: Journal of Erciyes University Faculty of Economics and Administrative Sciences, 34, pp. 189-212.

Özdevecioğlu, M. (2003). A research to determine the relationships between perceived organizational support and organizational commitment. Journal of Dokuz Eylul University Faculty of Economics and Administrative Sciences, 18(2), pp. 113-130.

Özgan, H., Çetin, B. \& Külekçi, E. (2011). Observing primary education grade teachers' organizational cynicism levels according to some specific variables. Journal of Social Sciences Research, 17, pp. 69-84.

Özgen, F. Ö. \& Turunç, Ö. (2017). the role of person organization fit in the relationship of cynicism and organizational justice a research in education sector. International Journal of Economics and Administrative Sciences, 3(2), pp. 80-96.

Özgener, Ş., Öğüt, A. \& Kaplan, M. (2008). A new paradigm in employee-employer relations: Organizational cynicism. Editörler: M. Özdevecioğlu \& H. Karadal. Selected topics in organizational behavior, dark aspects of organizations and efficiency reducing behavior (pp. 53-72). Ankara: Illke Publishing.

Peplinski, M. S. (2014). Perceived organizational support, organizational cynicism and employee well-being. Thesis, Master of Applied Psychology (MAppPsy). University of Waikato. Hamilton, New Zealand.

Pillai, R., Scandura, T. A. \& Williams, E. A. (1999). Leadership and organizational justice: Similarities and differences across cultures. Journal of International Business Studies, 30(4), pp. 763-779.

Meydan, C. H. Polat, M., \& Tokmak, İ. (2010). The effect of empowerment perception on organizational identification: a study on public sector. Science Journal of Turkish Military Academy, 20(1), pp. 37-60.

Polat, S. \& Celep, C. (2008). Perceptions of Secondary School Teachers on Organizational Justice, Organizational Trust, Organizational Citizenship Behaviors. Educational Administration: Theory and Practice, 54, pp. 307-331. 
Shaharruddin, S., Ahmad, F. \& Musa, M. M. (2016). Cynicism in organizations: does organizational justice matter? International Journal of Research in Business Studies and Management, 3 (2), 49-60.

Şamdan, T. ve Atanur Başkan, G. (2019). An Analysis of the Relationship between Organizational Justice and Organizational Cynicism According to the Perceptions of Teachers. Pamukkale University Journal of Education Faculty, 47, ss. 17-40.

Şirin, E. (2011). The relationship between teachers' perceptions of school culture and organizational cynicism attitudes in primary schools. Unpublished Master Thesis. Yeditepe University, Institute of Social Sciences, Istanbul / Turkey.

Titrek, O. (2009). The level of organizational justice in schools according to school types. International Journal of Human Sciences, 6(2), pp. 551-573.

Tokgöz, N. \& Yilmaz, H. (2008). Organizational cynicism: an investigation on hotel organizations in Eskisehir and Alanya. Anadolu University Journal of Social Sciences, 8(2), pp. 283- 305.

Torun, A. ve Üçok, D. (2014). The effects of negative attitudes and expectations on burnout: a study on cynical attitudes and perceived psychological contract breach. Atatürk University Journal of Economics and Administrative Sciences, 28(1), pp. 231-250.

Turgut, T. \& Agun, H. (2016). The Relationship between Organizational Justice and Organizational Cynicism: The Mediating Role of Psychological Capital and Employee Voice. Journal of Behavior at Work, 1(1), 15-26.

Turunç, Ö. (2011). The effect of organizatıonal justice and organizational identification on employee's turnover intention: the mediating effect of organizational identification. Is, guc" industrial relations and human resources journal, 13(1), pp. 143-166.

Tyagi, N., Moses, D. \& Rana, S. (2017). Influence of organizational justice on managerial effectiveness in institutions of higher learning. Productivity, 58(3), pp. 286-299.

Ünlü, Y., Hamedoğlu, M. A. \& Yaman, E. (2015). The relationship between perceived organizational justice and organizational silence level of teachers. Sakarya University Journal of Education, 5( 2), pp. 140-157.

Yavuz, E. (2010). A comparative study on organizational justice perception of public and private sector workers. Dogus University Journal, 11(2), pp. 302-312.

Yazıcıoğlu, İ. \& Gençer, E. Ö. (2017). The effect of organizational justice perception on cynicism: a research in vocational school of state universities. Journal of Business Research, 9(4), pp. 106-119.

Yazıcıoğlu, İ. \& Topaloğlu, I. G. (2009). Relationship between organizational justice and commitment: a case study in accommodation establishments. Journal of Business Research, 1(1), pp. 3-16.

Yilmaz, K. (2010). Organizational justice perceptions of teachers working in public secondary schools. Educational Sciences in Theory and Practice, 10(1), pp. 579-616. 
Author(s) will retain the copyright of their published articles agreeing that a Creative Commons Attribution 4.0 International License (CC BY 4.0) terms will be applied to their work. Under the terms of this license, no permission is required from the author(s) or publisher for members of the community to copy, distribute, transmit or adapt the article content, providing a proper, prominent and unambiguous attribution to the authors in a manner that makes clear that the materials are being reused under permission of a Creative Commons License. Views, opinions and conclusions expressed in this research article are views, opinions and conclusions of the author(s). Open Access Publishing Group and European Journal of Education Studies shall not be responsible or answerable for any loss, damage or liability caused in relation to/arising out of conflicts of interest, copyright violations and inappropriate or inaccurate use of any kind content related or integrated into the research work. All the published works are meeting the Open Access Publishing requirements and can be freely accessed, shared, modified, distributed and used in educational, commercial and non-commercial purposes under a Creative Commons Attribution 4.0 International License (CC BY 4.0). 